\title{
Isolation and identification of halophilic and halotolerant bacteria from the sediments of the Qeshm Island mangrove forest
}

\author{
Pegah Javid, ${ }^{1}$ Hassan Zadabbas Shahabadi, ${ }^{2}$ Homeyra Amirkhani, ${ }^{3}$ Narges Amrollahi Biuki,,${ }^{1 *}$ Mohammad Sharif Ranjbar ${ }^{1}$ \\ ${ }^{1}$ Department of Marine Biology, Faculty of Marine Science and Technology, University of Hormozgan, Bandar 'Abbas; ${ }^{2}$ Department \\ of Marine Biology, Faculty of Marine Sciences, Chabahar Maritime University, Chabahar; ${ }^{3}$ Microbiology Department; Food, Drug \\ and Standard Bureau of Qeshm Free Zone, Qeshm Island; ${ }^{4}$ Department of Modern Technology, Mangrove Forest Research Center, \\ University of Hormozgan, Bandar 'Abbas, Iran
}

\section{ABSTRACT}

Due to specific environmental and ecological conditions, mangrove forests are known as marine transitional zones between sea and land, and, as such, they host organisms with high ecological plasticity. The mangrove forests of Qeshm Island (Iran) are relatively pristine habitats and represent an ideal target for investigating patterns of either aquatic or benthic biodiversity. To provide insights on microbial diversity in this area, nineteen halophilic and halotolerant bacteria were isolated from the sediments in 2017 during low tide. The extracted bacterial strains were studied morphologically by streaking, initial observation of colonies and bacterial staining, and characterized using a battery of biochemical tests including KOH, MR, VP, urease, TSI, S/I/M, Mac, LIA, ODC, ADH, oxidase, catalase, and tryptophan deaminase. The optimum growth of halophilic bacteria was observed in salt concentrations from 5 to $20 \%$ $\mathrm{NaCl}$, whereas the extreme halophilic Gram-positive strain grew in salt concentration of up to $30 \% \mathrm{NaCl}$. Molecular analyses were also carried out on four halophilic strains and one extreme halophilic gram-positive bacteria. Phylogenetic taxonomy analysis, after 16S rDNA gene Sanger sequencing, revealed that the halophilic bacteria were closely related to the strain types of the genus Bacillus including Bacillus licheniformis, Bacillus velezensis, Bacillus Paralicheniformis and Bacillus sp. with 99\% bootstrap value. The extreme halophilic strain was associated to strains of Planococcus plakortidis with $100 \%$ bootstrap value.

\section{INTRODUCTION}

Mangrove forests are located in intertidal and transitional zones between aquatic and terrestrial environments (Lee et al., 2006) with special ecological conditions (Thu and Populus, 2007) and occur in up to $70 \%$ of tropical and subtropical coastlines worldwide. They are important for their ecological values, highly production (Ghosh et al., 2010), economic activities such as fisheries and aquaculture - and biogeochemical cycles (Thu and Populus, 2007; Zahed et al., 2010). They provide breeding and feeding areas for many macro- and micro-organisms.

The microbial community living in the sediments of mangrove forests are exposed to several spatially and temporally variable ecological, biogeographical and anthropogenic fetors, including abundance of organic and inorganic matter, food web structure, nutrient cycling and pollution (Ghosh et al., 2010). Since mangrove ecosystems endure periodic tidal flooding, environmental factors, such as nutrient availability and salinity, are highly variable, which make mangroves a unique ecosystem with specific characteristics (Holguin et al., 2006).

Qeshm Island is the largest island in the Persian Gulf (Salehipour Milani and Jafar Beglu, 2012), and its mangrove forests, covering about $67.5 \mathrm{~km}^{2}$ and located within the northwest estuaries of the island, in Khoor-ekhooran and sandy islands apposite villages of Tabl and Laft to Gooran $\left(55^{\circ} 63^{\prime} \mathrm{E}-26^{\circ} 75^{\prime} \mathrm{N}\right.$ and $55^{\circ} 80^{\prime} \mathrm{E}-26^{\circ}$ $93^{\prime} \mathrm{N}$ ), are protected areas, international wetlands and biosphere reserves (Zahed et al., 2010). They are also the largest area of mangrove forests in the northern part of the Persian Gulf (Khosravi, 1992).

The Persian Gulf is experiencing stressful conditions due to high seasonal variations in temperature $\left(<10^{\circ} \mathrm{C}\right.$ in winter and $>30^{\circ} \mathrm{C}$ in summer) (Khosravi, 1992; Zehzad and Majnounian, 1997). Annual rainfall in Iranian mangrove forests is typically $<200 \mathrm{~mm}$, evaporation exceeds rainfall (Joekar and Razmjoo, 1995) and, thus, salinity is high (38 to 50) (Zahed et al., 2010; Salehipour Milani and Jafar Beglu, 2012). As a consequence, life in these environments shows a high tolerance to salinity and heat stress (Yan and Sinica, 2007).

The hypersaline environments which are derived from the sea could be divided into four groups according to the salinity range and organism origin: i) $6-7$ to $10 \%$ salinity includes originally marine various biota, ii) $10-14 \%$ salinity includes usually halotolerant, halophilic or adapted biota, iii) $14-30 \%$ salinity includes both extremely and moderately halophilic bacteria, iv) more than $30 \%$ salinity contains only bacterial community living on the organic matter (Por, 1980). According to the microorganism's ranges of salinity tolerance, they are categorized into three groups: slightly, moderately and extremely halophiles (Ventosa et al., 2006; Zhang et al., 2014). Halophilic bacteria can be present in almost all hypersaline environments including marine or terrestrial, anaerobic or aerobic, polar and tropical, or acidic to alkaline environments (Javor, 2012).

Microorganisms from extreme environments are able to enhance oil recovery and bioremediation (Lima et al., 2011), and produce important secondary compounds with potential to be used in pharmaceutical industries, 
agriculture, etc. (Janek et al., 2010). Isolated strains including Bacillus sp. from more tough environments, such as marine and salty sediments can produce surfactin products (Kiran et al., 2010; Donio et al., 2013). As an example, Bacillus subtilis is able to produce a cyclic lipopeptide surfactin, which is known as one of the most powerful surfactants (Kiran et al., 2010). This product is active at extreme salinity, temperatures and $\mathrm{pH}$ levels (Pacwa-Plociniczak et al., 2011). Other biological products, such as biosurfactants and antibiotics, are also produced by microorganisms living in extreme environments (AbdelMawgoud et al., 2008). Although the molecular evolution of stability and life of macromolecules has not been fully revealed yet (Vasavada et al., 2006), the survival and proliferation of microorganisms in extreme environmental conditions could depend on their ability to produce biologically active compounds (Valentine 2007), which in turn, could reasonably have a pharmaceutical importance. As an example, a pharmacologically important biosurfactant isolated from a halophilic Bacillus sp. BS3 at extreme environment of solar salt work has anticancer activity in breast cancer and antiviral activity in shrimps' white spot syndrome (Donio et al., 2013). Also, halophilic bacteria are suitable choices for bioremediation of hypersaline habitats (Zhang et al., 2014).

Many studies have indicated that due to the high diversity of bacterial species, evaluation of bacterial diversity using culture-dependent methods may lead to inaccurate information. Therefore, over the past two decades, many researchers have turned from culturedependent approaches to molecular (16S rRNA-dependent) approaches. Although this change of method has led to the discovery of many new species of microbes, bacterial cultivation, wherever possible and with exclusion of viable but non-culturable (VBNC) bacteria (Li et al., 2014), remains the best method to investigate their physiology under variable ecological conditions (Yeon et al., 2005).

Culture-dependent methods can be technologically enhanced by molecular techniques and molecular analysis. Also, PCR-based methods following DNA technologies could be complementary for cultivationdependent studies in order to discover the biodiversity or genetic differences of bacterial communities (Yoon et al., 2003; Fry, 2004; Yeon et al., 2005).

Studies on bacteria communities of soils and sediments have been conducted worldwide. In mangrove sediments, among the others, studies have been carried out on the diversity and biotechnology potential of bacteria in Brazil (Dias et al., 2009), isolation of Bacillus swezeyi sp. nov. and Bacillus haynesii sp. nov. from Negev Desert of Isreal (Dunlap et al., 2017), bacterial biodiversity in Sundarban, India (Ghosh et al., 2010), recovery of novel bacteria diversity in China (Liang et al., 2007), and so on.

To provide insights on microbial diversity in mangrove sediments, we have isolated and characterized, for the first time ever, some bacterial strains from the sediments of the Qeshm mangrove forests in Iran.

\section{METHODS}

\section{Sampling}

Sediment sampling was carried out with sterile pestles in September 2017 from the northwestern part of the mangrove forests in Qeshm Island, at Soheili jetty $\left(26^{\circ}\right.$ $78^{\prime} \mathrm{N}, 55^{\circ} 76^{\prime} \mathrm{E}$ ) (Fig. 1) during the maximum low tide from three zones of upper intertidal - near tree coverage (A); intertidal (B); and under tidal zones - near the sea water $(C)$. The sediment samples were collected in sterile glass jars, put into ice powder and then transported to the laboratory in $4^{\circ} \mathrm{C}$ refrigerator for further analyses.

\section{Bacteria cultivation, purification, and staining}

Sediment samples from the three zones (A, B and C) were initially dissolved in $0.85 \% \mathrm{NaCl}$ solutions. Different dilutions of $10^{-1}, 10^{-2}$ and $10^{-3}$ were then prepared and cultured in Nutrient Agar (NA) at $30^{\circ} \mathrm{C}$ for 24 and 48 hours. Then, the grown colonies were isolated on new NA cultures for subsequent biochemical tests, staining, and molecular studies. $\mathrm{NaCl}$ tolerance of strains and their growth were tested. More specifically, for assays of salt tolerance, Nutrient Broth (NB) medium was supplemented with different sodium chloride concentrations of $5 \%, 10 \%, 15 \%, 20 \%, 25 \%$ and $30 \%$ $(\mathrm{w} / \mathrm{v})$. The isolated strains in different $\mathrm{NaCl}$ concentrations were incubated at $30^{\circ} \mathrm{C}$ and monitored for growth after 24 and 48 hours. The Gram reaction of bacteria was determined by Gram staining set (Qatran Shimi, Iran). Gram staining is a useful method for detecting the structure of bacterial cell wall. According to the wall structure of bacterial cell, after staining, they show a purple appearance in Gram-Positive bacteria or red in Gram Negative ones. Staining was followed in accordance with manufacturer's protocol. Growth and common biochemical tests for identification of microorganisms were performed as follows: $\mathrm{KOH}$ test (potassium hydroxide test) with 3\% $\mathrm{KOH}$ solution was carried out for confirming the gram staining process. Catalase test was conducted for finding out whether the strains had catalase enzyme for decomposition of $\mathrm{H}_{2} \mathrm{O}_{2}$; MR (Methyl Red)/VP (VoguesProskauer) test was used to distinguish and identify the general forms of bacteria and identify the final product of bacterial fermentation pathway. Urease test was done in urease broth medium culture to determine which strain produced the urease enzyme that hydrolyzes urea to ammonia and carbon dioxide. Sugar fermentation test was used in differential TSI or Triple Sugar Iron Agar culture medium containing three types of sugar (lactose, sucrose 
and glucose). This test was carried out to differentiate the microorganisms according to their ability in reduction of sulfur and fermentation of carbohydrates. Sulfur reduction, indole production ability, and motility of strains were tested through culturing in SIM (sulfur, indole, and motility) medium to differentiate the strains.

Culturing in MacConkey agar was carried out for detection of gram-negative bacteria. The decarboxylation tests show the microorganism's ability in removing the carboxyl group from an amino acid, and are useful for the differentiation of Enterobacteriaceae. The decarboxylation test for Lysine amino acid was carried out in lysine iron agar (LIA). Ornithine decarboxylation test was conducted in ornithine decarboxylase agar (ODC). Arginine dihydrolase test was done with culturing the bacteria in arginine dihydrolase broth (ADH) medium to detect the bacteria producing arginine dihydrolase enzyme that decarboxylates arginine. Oxidase test was carried out to identify the organisms producing cytochrome oxidase enzyme. Indole test was carried out by culturing strains in tryptophan broth. This test shows the ability of bacteria in converting tryptophan into indole.

\section{DNA extraction, PCR conditions, and molecular identification}

The bacteria were cultured in $10 \mathrm{cc}$ tryptophan broth and yeast extract with $10 \%$ salinity for proliferation. DNA was extracted by Genomic DNA Extraction Kit from Gram-Positive Bacteria (Gene Transfer Pioneers, Iran) and suspended in $30 \mathrm{ml}$ elution buffer. Extracted DNA quality was evaluated by $1.5 \%$ agarose gel electrophoresis using Tris-borate-EDTA as the buffer and RedSafe ${ }^{\mathrm{TM}}$ (iNtRON, South Korea) for gel staining.

The extracted DNA was used as a template for amplification and sequencing. The universal bacterial primers, 27F (Forward: 5'-AGA GTT TGA TCM TGG CTC AG-3') (Lane, 1991) and 1525R (Reverse: AAG GAG GTG WTC CAR CC) (Lane, 1991) were used for amplification of 16S rDNA genes by Polymerase Chain Reaction. PCR reactions were carried out in $25 \mu \mathrm{L}$ of master mix, with $2.5 \mu$ of 10X PCR buffer (BIORON, Germany), $1.25 \mu \mathrm{l}$ of $100 \mathrm{mM} \mathrm{MgCl} 2$ (BIORON, Germany), $1 \mu \mathrm{l}$ of $25 \mathrm{mM}$ dNTPs (GeneAll, Korea), $1 \mu \mathrm{l}$ of each $10 \mathrm{pM}$ forward and reverse primer (Pishgam, Iran), 5 U Taq DNA polymerase, and about $15 \mathrm{ng} \mu \mathrm{L}^{-1}$ of template.

The 16S rDNA was amplified using a DNA thermal

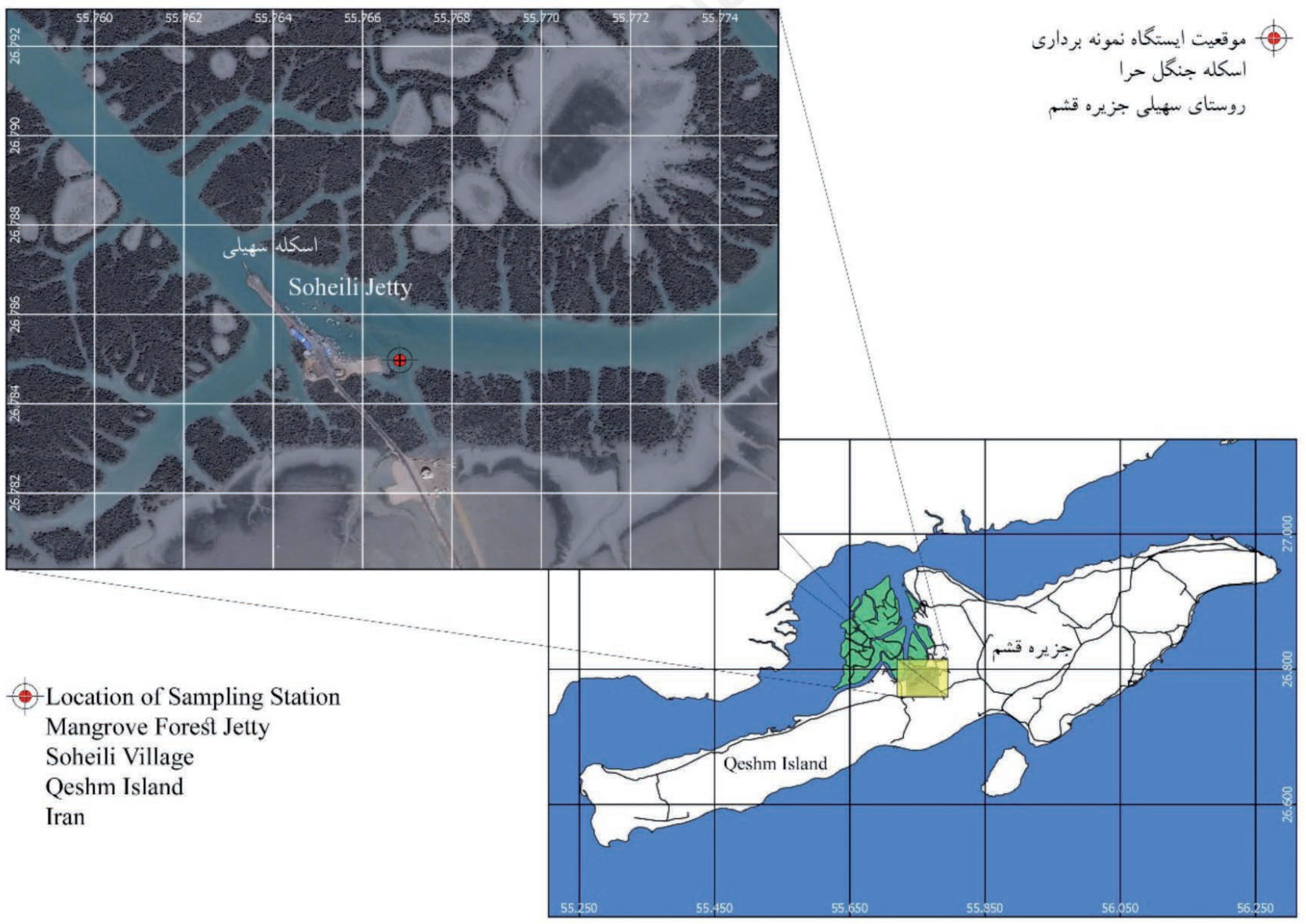

Fig. 1. Map of sampling site on Mangrove forest, Soheili jetty, the Northwestern part of Qeshm Island, Iran. Credit: Eghbal Zobeiri. 
cycler with the following profile: $95^{\circ} \mathrm{C}$ for $4 \mathrm{~min} ; 38$ cycles of $94^{\circ} \mathrm{C}$ for $1 \mathrm{~min}, 56.5^{\circ} \mathrm{C}$ for $1 \mathrm{~min}$, and $72^{\circ} \mathrm{C}$ for $2 \mathrm{~min}$ and $30 \mathrm{~s}$; and a final cycle of $72^{\circ} \mathrm{C}$ for $10 \mathrm{~min}$. PCR products were visualized through $1 \%$ agarose gel, and the PCR products were sequenced through Sanger DNA sequencing method by BIONEER Company, South Korea. The sequences were blasted in the National Center of Biotechnology Information (NCBI) in order to identify the strains. According to the blast results in NCBI, the strains with the most similarity and high percentage of identity were selected for finding the phylogenetic taxonomy relationships. The sequencing data were aligned and edited using CLUSTALX (Larkin et al., 2007) to obtain overlapping and equal segments. Then the phylogenetic analysis was done in MEGA 7 (Kumar et al., 2016) for designing the tree and finding the relations between strains. Bootstrap consensus tree was obtained by NJ analysis from 1000 replicates. Bootstrap analysis was done to determine the limits of the branching. The phylogenetic tree was rooted in Alicyclobacillus acidocaldarius as the outgroup.

\section{RESULTS}

\section{Biochemical and growth features of bacterial strains}

From Qeshm mangrove sediments, 19 cultivable strains were isolated on the basis of morphology, color, Gram staining, biochemical tests, growth activity and salinity resistance. Molecular identification was carried out on five out of the 19 strains. All bacteria were GramPositive. Tab. 1 shows the biochemical and growth features of five molecularly identified strains and Tab. 2 shows the growth status of strains in different salinities. Strains 1 and 2 were isolated from sediments of zone A, strain 3 was isolated from sediments of zone B, and strains 4 and 5 belonged to sampled sediments from zone $\mathrm{C}$.

\section{Molecular identification and phylogenetic analyses}

The 16S rDNA gene sequences consisted of $967 \mathrm{bp}$ for strain 1, 1436 bp for strain 2, 1442 bp for strain 3, $1441 \mathrm{bp}$ for strain 4 and $1047 \mathrm{bp}$ for strain 5. They were blasted in the NCBI database, and were compared with other species.

Tab. 1. Biochemical and growth features of 5 molecularly identified strains.

\begin{tabular}{|c|c|c|c|c|c|}
\hline Features/Strains & Strain 1: PG-1-MS & Strain 2: PG-2-MS & Strain 3: PG-3-MS & Strain 4: PG-4-MS & Strain 5: PG-5-MS \\
\hline Gram & + & O & + & + & + \\
\hline $\mathrm{KOH}$ & - & 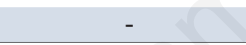 & - & - & - \\
\hline MR & - & - & - & - & - \\
\hline VP & + & - & - & - & - \\
\hline Urease & - & - & + & + & - \\
\hline TSI & Alk/Alk & Alk/Alk & $\mathrm{Alk} / \mathrm{Ac}$ & $\mathrm{Alk} / \mathrm{Ac}$ & Alk/Alk \\
\hline $\mathrm{S} / \mathrm{I} / \mathrm{M}$ & $-1-1+$ & $-1-1+$ & $-1-1+$ & $-1-1+$ & $-1-1+$ \\
\hline Mac & - & - & - & - & - \\
\hline LIA & - & + & + & + & + \\
\hline ODC & - & - & - & - & - \\
\hline $\mathrm{ADH}$ & - & - & - & - & - \\
\hline Oxidase & + & + & + & - & + \\
\hline Catalase & + & - & - & - & + \\
\hline Ttryptophan deami & lase & - & - & - & - \\
\hline
\end{tabular}

Alk, alkaline reaction; Ac, acid production.

Tab. 2. Bacterial growth in different concentrations of sodium chloride. The bold columns show the strains identified by molecular study (1: PG-1-MS; 4: PG-2-MS; 7: PG-3-MS; 16: PG-4-MS; 19: PG-5-MS). Positive items show the strains' growth in different concentrations of $\mathrm{NaCl}$.

\begin{tabular}{|c|c|c|c|c|c|c|c|c|c|c|c|c|c|c|c|c|c|c|c|}
\hline Salinity $\% /$ Strains & 1 & 2 & 3 & 4 & 5 & 6 & 7 & 8 & 9 & 10 & 11 & 12 & 13 & 14 & 15 & 16 & 17 & 18 & 19 \\
\hline 0 & + & + & + & + & + & + & + & + & + & + & + & + & + & + & + & + & + & + & + \\
\hline 5 & + & + & + & + & + & + & + & + & + & + & + & - & + & + & + & + & + & + & + \\
\hline 10 & + & + & + & + & + & + & + & + & + & + & + & - & + & + & + & + & + & + & + \\
\hline 15 & - & - & - & - & - & - & + & - & - & + & + & - & + & + & - & + & - & + & + \\
\hline 20 & - & - & - & - & - & - & + & - & - & - & - & - & - & - & - & + & - & + & + \\
\hline 25 & - & - & - & - & - & - & - & - & - & - & - & - & - & - & - & - & - & - & + \\
\hline 30 & - & - & - & - & - & - & - & - & - & - & - & - & - & - & - & - & - & - & + \\
\hline
\end{tabular}


Molecular identification of the 16S rDNA gene sequences includes 12 strains of Bacillus sp. Bacillus licheniformis and Bacillus paralicheniformis in Clade 1 (Cl1), 6 strains of Bacillus velezensis in Clade $2(\mathrm{Cl} 2)$ and 9 strains of Planococcus plakortidis and Planococcus maritimus in Clade $3(\mathrm{Cl} 3)$ along with one outgroup. The analysis in this study showed that strains in the same clade are sister groups and clade 1 and 2 are supported as monophyletic groups with a bootstrap value of $100 \%$. The blast results of $\mathrm{Cl} 1$ showed that PG-1-MS is associated with the species of Bacillus licheniformis strains of this clade with 99.90\% (KJ526876.1, KJ526860.1, and EF472268.1) and $99.79 \%$ (MG980062.1) identities. In the same clade, the strain PG-3-MS has high identity with other strains of Bacillus paralichenifirmis $(100 \%$ identity with strain MH538129.1 and 99.93\% identity with strains CP023666.1 and MF321832.1). Meanwhile, MH538129.1 and CP023666.1 have lower identity (99.79\%) with Bacillus licheniformis. In addition, PG-4-MS was identified as Bacillus sp., and had 100\% identity with other Bacillus sp. strains (MG814028.1 and MG814024.1) in the blast result, while the identity of PG-4-MS with Bacillus paralicheniformis is $99.93 \%$. Another bootstrap value of $100 \%$ shows that clade 3 is paraphyletic for the previous monophyletic groups. The Clade 1 contains strains 1, 3 and 4 of the recorded mangrove sediment bacteria. Clade 2 has all Bacillus velezensis strains including our strain 2. Clade 3 , as a paraphyletic group in the phylogenetic tree, includes the species Planococcus plakortidis, which corresponds to our strain 5. Strains PG-1-MS, PG-2-MS, PG-3-MS, and PG-4-MS belong to genus Bacillus, whereas PG-5-MS belongs to genus Planococcus. About 967 bp for PG-1-MS (Accession Number: MH847742.1) and 1442 bp for PG-3MS (Accession Number: MH842119.1) were analyzed in the final alignment.

PG-1-MS and PG-3-MS were closely related to Bacillus licheniformis and Bacillus paralicheniformis, respectively ( $99 \%$ bootstrap value). The PG-4-MS (Accession Number: MH842120.1) was related to strains PG-1-MS and PG-3-MS and genus Bacillus with 99\% bootstrap value, but other tests and biochemical analyses showed different results from other identified species mentioned in Tab. 1. The Neighbor-Joining phylogenetic tree (Fig. 2) revealed that strain PG-2-MS (Accession Number: MH838019.1) belongs to species Bacillus velezensis and is related to the other strains of species Bacillus velezensis with $99 \%$ bootstrap value. Blast results also showed that PG-2-MS has $100 \%$ identity with other strains of Bacillus velezensis (MF662480.1, MF662477.1, MF662476.1, MF662472.1, and MF662470.1) presented in clade 2. The last strain PG-5-MS (Accession Number: MH842121.1) is associated with other species of Planococcus plakortidis with $100 \%$ bootstrap value in phylogenetic taxonomy analysis.
Blast results revealed that PG-5-MS has more than 95.52\% (MG705879.1, and MG705828.1) and 99.60\% (MH384429.1, CP016539.2, NR_109414.1) identity with identity with Planococcus plakortidis. Although these blast results showed close relation between PG-5-MS and Planococcus maritinus (MG705829.1) with 99.52\% identity, biochemical characteristics showed more similarity of PG-5-MS to P. plakortidis. Thus, the highest bootstrap values among our strains and other species of genus Bacillus and Planococcus were 99\% (Bacillus sp., Bacillus licheniformis, Bacillus paralicheniformis, Bacillus velezensis) and 100\% (Planococcus plakortidis), respectively.

Strains PG-1-MS, PG-2-MS, PG-3-MS, and PG-4-MS showed common features with genus Bacillus as they were all Gram-positive, rod-shaped, endospore-forming, motile and aerobic. PG-1-MS and PG-2-MS grew in up to $10 \%$ salinity in $\mathrm{NB}$, but not in higher $\mathrm{NaCl}$ concentrations. PG-3-MS and PG-4-MS tolerated more salinity and grew in enriched NB with $20 \% \mathrm{NaCl}$. The growth condition in $\mathrm{NB}$ enriched by $\mathrm{NaCl}$, interestingly, showed that PG-5-MS is an extreme halophilic strain that grew in $30 \% \mathrm{NaCl}$ concentration.

Strain PG-1-MS belongs to aerobic, endospore-forming motile rod bacteria that produced yellow glossy round shaped with regular margin colonies in the NA. This halotolerant strain was molecularly identified as a strain of Bacillus licheniformis (more than 99.79\% identity with other strains of Bacillus licheniformis in clade 1; Accession Number: MH837742.1). Strain PG-2-MS, molecularly identified as a strain of Bacillus velezensis (100\% identity with other strains of Bacillus velezensis in clade 2 and 100\% bootstrap value; Accession Number: MH838019.1), was aerobic Diplococcus bacteria with creamy white flat, viscose and irregular-margin colonies in the NA. Strain PG3-MS, recorded as a strain of Bacillus paralicheniformis (more than $99.93 \%$ identity with other strains of Bacillus paralicheniformis in clade 1; Accession Number: MH842119.1), was an aerobic bacteria that formed convex, multilayered mounds of flower-like or amorphous, slime, approximately colorless (very light creamy-white) colonies with 2-3 $\mathrm{mm}$ in diameter in the NA culture. Strain PG-4MS, identified as a strain of Bacillus sp. (99.93\% identity with other strains of Bacillus sp. in clade 1; Accession Number: MH842120.1), formed spreading edged mucoid transparent light pinkish colonies on NA culture. Strain PG5-MS, the strain of Planococcus plakortidis (more than $99.5 \%$ blast identity and $100 \%$ bootstrap value; Accession Number: MH842121.1), was gram-positive, non-spore forming, slow-growing, aerobic coccoid bacteria, and produced colonies with approximately $1 \mathrm{~mm}$ in diameter after about 72 hours at $30^{\circ} \mathrm{C}$. The colonies were smooth, glossy, circular, small and round-shaped with regularmargin in orange on NA culture. 


\section{DISCUSSION AND CONCLUSIONS}

Mean seawater salinity is ca. 35, and many microorganisms which live at this salinity can endure slightly higher salinities, whereas only halotolerant and halophilic species can grow in extremely hypersaline environments (Javor, 2012). Although, in comparison to other habitats, hypersaline environments possess low prokaryotic diversity (Guixa-Boixareu et al., 1996), they are home to a high diversity of halotolerant bacteria and extremely halophilic bacteria (Yoon et al., 2003). The microorganisms that tolerate very high salinity values show different metabolic features adapted to such extreme conditions (Zhang et al., 2014).

The genus Bacillus consists of various species with some general characteristics: rod-shaped, and chainforming gram-positive bacilli which can grow anaerobically or aerobically (Thwaite and Atkins, 2012), the majority of them being motile and having lateral flagella (Stoica and Ionut, 2017). Their function in biochemical tests, growth features and even the phenotype of sporangia can influence their classification, and they can cope with unfavorable growth conditions due to their endospores (Zeigler and Perkins, 2015). Members of the genus Bacillus possess variable features and can live in different environments, or endure environmental variations of oxygen availability, humidity, temperature and nutrient accessibility (Nicholson, 2002). For example, different species of Bacillus might be aerobic or anaerobic, Grampositive or Gram-variable and live in all environments from dust, soil and water (La Jeon et al. 2012) to skin and human gut (Mandell et al., 2010). Bacillus anthracis and Bacillus cereus are human pathogens (Farrar, 1963). Bacillus cereus populations are endosymbionts in the gut of cockroach species Blaberus giganteus and have nutritional advantage for these insects (Feinberg et al., 1999). It is reported that the species Bacillus infernus has been found nearly $3 \mathrm{~km}$ below the surface of earth (Boon et al., 1995). Some even

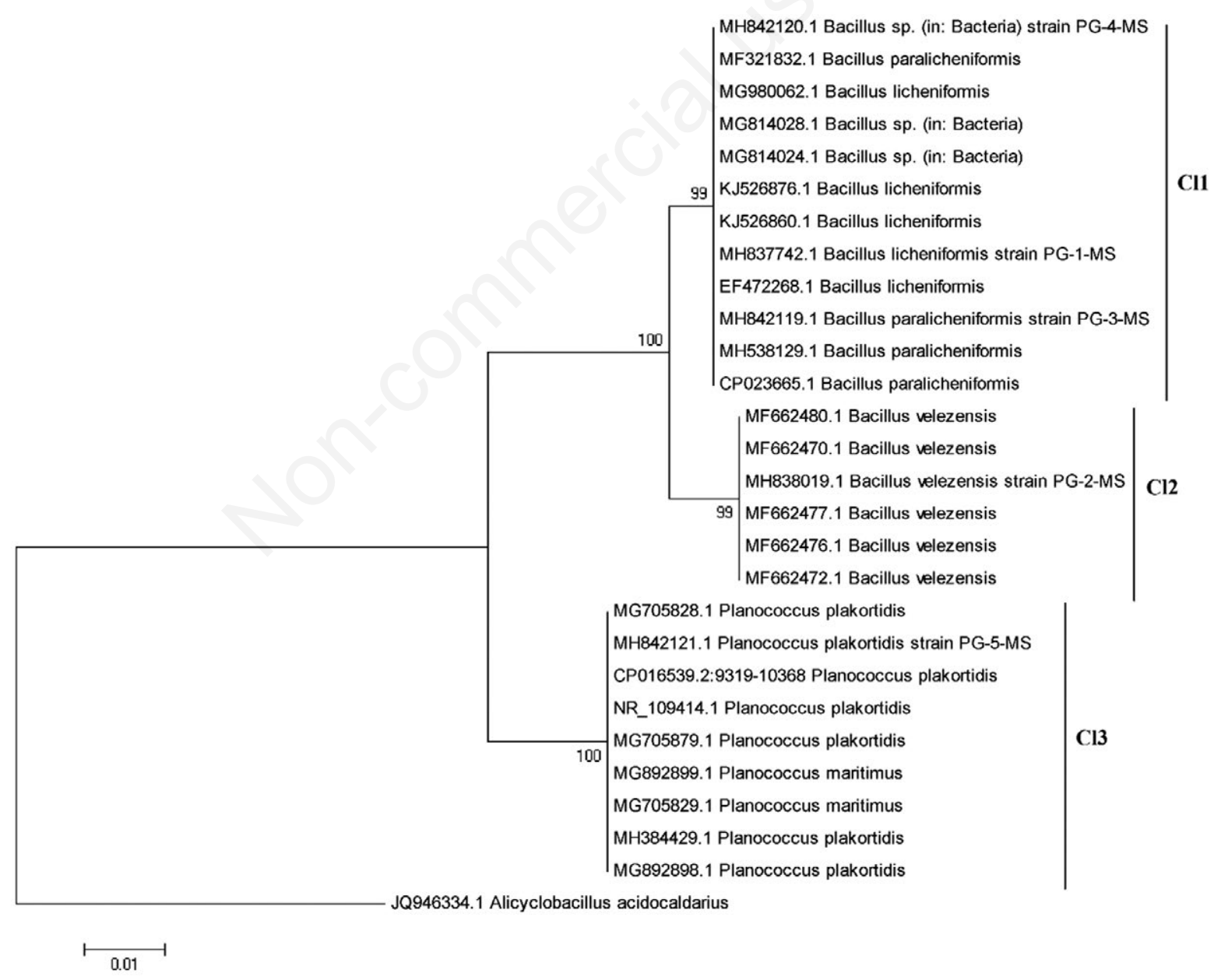

Fig. 2. Neighbor-joining phylogenetic tree for 27 strains, including Qeshm Mangrove Sediment species (PG-1-MS to PG-5-MS), based on $16 \mathrm{~S}$ rDNA sequences. The numbers beside the branches are bootstrap values with 1000 replications. Alicyclobacillus acidocaldarius is selected as the outgroup. 
could be found in extreme salty ecosystems such as solar salt works and condenser water with $155 \mathrm{ppt}$ of salinity (Donio et al., 2013). Any species might include different strains, which are sympatric (Palmisano et al., 2001), so it is obvious that different strains of a species do not show the same features. Although there are strains of bacteria which are not potentially halophilic, with the passage of time, they can tolerate salinity as they adapt to their environment (Zhang et al., 2014). The species of genus Bacillus have been increasingly important in applied microbiology and biochemical studies such as production of natural products, antibiotics, surfactants and enzymes (Ruiz-Garcia et al., 2005; Jasim et al., 2016). They have been studied also as probiotics in fish food and used as feeding supplement in aquaculture (Martínez Cruz, 2012; Ramesh et al., 2015; Meidong et al., 2017) and livestock (Kaewtapee et al., 2017) for improving performance and health in animals (Meng et al., 2010). Especially, Bacillus licheniformis and Bacillus subtilis have been used as pig supplementary diet (Larsen et al., 2014; Jørgensen et al., 2016). Different species of genus Bacillus could be found in various habitats from nature and plants (Arnesen et al., 2008; Jasim et al., 2016), and in intestinal tract of insects and mammals (Arnesen et al., 2008) to soil (Palmisano et al., 2001; Dunlap et al., 2017) and water (Arjmand et al., 2016). Bacillus enfolds about 70 species (Thwaite and Atkins, 2012) four of which have been recently presented as surfactant-producing bacteria, including Bacillus licheniformis (Weigmann, 1898) and Bacillus velezensis (Ruiz-Garcia et al., 2005) isolated from Velez River in southern Spain for the first time, Bacillus paralicheniformis (Dunlap et al., 2015) that have been isolated from fermented soybean paste for the first time, and Bacillus sp. which have been studied in the present paper.

As it was mentioned before, according to the continuously increasing number of identified bacteria with high similarity to each other, recognition via classical identification methods - such as analysis of physiological and morphological characteristics, the composition of cell walls and biochemical features - is very difficult (Fan et al., 2017). There might be some other features other than morphology and biochemistry characteristics which make microorganisms distinguished from each other such as DNA sequences, fatty acid composition and even resistance to genetic transformation; these kinds of differences might exist even among the species of the same genus (Bacon and Hinton, 2011). Thus, there might exist some biochemical features which vary among species of a genus or strains of a species. The genus Planococcus was identified more than one century ago by Migula (1894), and was later modified by Nakagawa et al. (1996) (Migula, 1894; Nakagawa et al., 1996; Kaur et al., 2012). Some species of this genus are alkaliphilic and thermotolerant. A novel strain of species Planococcus plakortidis was isolated from a marine sponge, Plakortis simplex (Kaur et al., 2012) and received the authority by Kaur et al. (2012).

Planococcus plakortidis isolated from a genus of marine sponge showed positive activity for both catalase and oxidase (Kaur et al., 2012) while Planococcus sp. MC01 (99.3\% nucleotide identity with Planococcus plakortidis) (Ma et al., 2013) and Planococcus maritimus (Yoon et al., 2003) were found to be Catalase-Positive and Oxidase-Negative. Additionally, in our study, Planococcus plakortidis PG-5-MS had negative and positive activity for catalase and oxidase, respectively.

Our phylogenetic taxonomy analysis using $16 \mathrm{~S}$ rDNA through NJ phylogenetic tree showed that clade Cl1 includes Bacillus licheniformis, Bacillus paralicheniformis, Bacillus sp. and their similar strains in a species, clade $\mathrm{Cl} 2$ consisted of Bacillus velezensis and similar strains and clade $\mathrm{Cl} 3$ possess Planococcus plakortidis and its strains (Fig. 2). The affinity of molecularly identified strains in trees showed $99 \%$ or more bootstrap value with other strains.

Bacillus licheniformis is a halophilic species, and different studies have shown that the presence of $\mathrm{NaCl}$ in the medium has better effects on bacterial growth and the production of bacterial products. There was positive growth on the medium enriched by $7 \% \mathrm{NaCl}(\mathrm{v} / \mathrm{w})$, and the grown bacteria successfully produced tannin acyl hydrolase (Mondal and Pati, 2000). $\mathrm{NaCl}$ concentration in the modified medium of a strain of Bacillus licheniformis isolated from saline soil had positive effect on $\gamma$-PGA production resulting in the most volumetric yield of this product $\left(13.86 \mathrm{~g} \mathrm{l}^{-1}\right)$ as the medium was enriched by $8 \% \mathrm{NaCl}$; the strain had positive growth in $12 \%$ concentration of $\mathrm{NaCl}$ as well (Wei et al., 2010). Interestingly, the phylogenetic analysis has also revealed that two strains of genus Bacillus (Bacillus swezeyi and Bacillus haynesii) had a close relationship with the clade that included Bacillus licheniformis and its members, and they showed tolerance to up $12 \% \mathrm{NaCl}(\mathrm{w} / \mathrm{v})$ (Dunlap et al., 2017). Shivaji et al. (2006) showed that Bacillus licheniformis forms white irregular, fried-egg-like colonies on NA, tolerated up to $11.6 \% \mathrm{NaCl}(\mathrm{v} / \mathrm{w})$ but not $17.4 \%$ and $23.4 \%$ concentrations of $\mathrm{NaCl}(\mathrm{v} / \mathrm{w})$.

Bacillus velezensis showed growth capability at $12 \%$ w/ $/ \mathrm{NaCl}$ concentration and a temperature range of 15$45^{\circ} \mathrm{C}$; also, grew on TSA medium while producing rough white-creamy colonies with irregular edges (Ruiz-Garcia et al., 2005), which was not far from our observations on this strain grown in NA. Bacillus velezensis was reported as a bacterium which acts as a plant growth promoting strain (Fan et al., 2017). Presence of strain Bacillus velezensis in the collected sediments close to the plants in our research further proves the role of this strain in rhizosphere colonization. Dunlap et al. (2015) recorded a strain of Bacillus paralicheniformis as absolute anaerobic 
gram-positive, motile strain that can form creamy mucoid, semitransparent colonies with 3-4 $\mathrm{mm}$ in diameter on R2A agar that can tolerate $\mathrm{NaCl}$ concentrations up to $10 \%$ (w/v) (Dunlap et al., 2015).

Planococcus plakortidis was identified as a grampositive coccoid strain for the first time in 2012 from the Bay of Bengal (Kaur et al. 2012). Planococcus sp. has been reported as a halotolerant and alkaliphilic slowgrowing bacterium with orange-red colonies and $2-3 \mathrm{~mm}$ in diameter that grew after two days while the optimal temperature was $30^{\circ} \mathrm{C}$; in this study, the growth occurred at from $2 \%$ to $17 \%(\mathrm{w} / \mathrm{v}) \mathrm{NaCl}$ (Ma et al., 2013). The strains of Planococcus maritimus with $100 \%$ bootstrap value in $\mathrm{Cl} 3$ with Planococcus plakortidis and its strains in our study showed high affinity. Planococcus maritimus was isolated from seawater of the tidal zone in Korea for the first time. The biochemical characteristics of this species, however, showed either similarities (Grampositive, cocci, motile, positive growth in $0 \% \mathrm{NaCl}$, negative urease) or dissimilarities (positive catalase, negative oxidase, tolerant to different salinities) (Yoon et al., 2003) to the putative Planococcus plakortidis strain isolated in our study. Positive growth in $15-17 \%(\mathrm{v} / \mathrm{w})$ concentration of $\mathrm{NaCl}$ by Planococcus maritimus in Yoon et al. (2003) survey and the same result in up to $12 \% \mathrm{NaCl}$ (v/w) by the strains of Planococcus sp. in Dunlap et al. (2017) study showed that this genus is halotolerant.

Thus, based on our findings, we conclude that the identified halophilic bacteria isolated from the sediments of the mangrove forests in Qeshm Island, South of Iran, were mostly from genus Bacillus and Planococcus, which possess variant species and strains with different degrees of tolerance to salinity. Our phylogenetic analysis showed a close relationship between different identified strains with previous studies and recorded strains. Strains PG-1-MS, PG-3-MS and, PG-4-MS in C11, Strain PG-2-MS in Cl2 and Strain PG-5-MS in $\mathrm{Cl} 3$ lie in monophyletic groups. The noted strains generally formed clades in a phylogenetic tree with more than $98 \%$ bootstrap value protection.

The results presented in our spot survey in the mangrove sediments of Qeshm Island, South of Iran, confirm that this ecosystem hosts a peculiar diversity of halophilic bacteria with bio-ecological and functional characteristics either similar or different from those of similar strains isolated from other environments. The results presented here suggest that the prokaryotic diversity of this peculiar ecosystem deserves further attention, also in order to identify microorganisms that could possess a valuable potential in bioremediation and better growth of halophile plants.

\section{ACKNOWLEDGMENTS}

This research was granted by the University of Hormozgan. We are grateful to Kazem Ghorbani, the head of Drug and Standard Bureau of Qeshm Free Zone, for his kind permission for working in the Microbiology department, and to Somayeh Kouchaki for her efforts in coordination. We also thank Somayeh Mohammadi for her valuable contribution at the Microbiology department. We are grateful to Eghbal Zobeiri for designing the map picture. The authors would also like to thank Novin Biotechnology Department of Isfahan for provision of facilities during molecular experiments.

Corresponding author: amrollahi@hormozgan.ac.ir

Key words: Halophiles; extreme halophile; halotalerant; grampositive; molecular identification; mangrove sediments.

Received: 8 December 2019.

Accepted: 16 March 2020.

This work is licensed under a Creative Commons Attribution NonCommercial 4.0 License (CC BY-NC 4.0).

${ }^{\circ}$ Copyright: the Author(s), 2020

Licensee PAGEPress, Italy

Advances in Oceanography and Limnology, 2020; 11:8743

DOI: 10.4081/aiol.2020.8743

\section{REFERENCES}

Abdel-Mawgoud AM, Aboulwafa MM, Hassouna NAH, 2008. Characterization of surfactin produced by Bacillus subtilis isolate BS5. Appl. Biochem. Biotechnol. 150:289-303.

Arjmand MM, Rezaee A, Nasseri S, Eshraghi SS, 2016. Removing Bacillus subtilis spores from drinking water using a bipolar electrochemical method. Int. J. Electrochem. Sc. 11:10080-10086.

Boone DR, Liu Y, Zhao ZJ, Balkwill DL, Drake GR, Stevens TO, Aldrich HC, 1995. Bacillus infernus sp. nov., an Fe(III)and $\mathrm{Mn}(\mathrm{IV})$-reducing anaerobe from the deep terrestrial subsurface. Int. J. Systematic Bacteriol. 45:441-448

Dias AC, Andreote FD, Dini-Andreote F, Lacava PT, Sá ALB, Melo IS, Azevedo JL, Araújo WL 2009. Diversity and biotechnological potential of culturable bacteria from Brazilian mangrove sediment. World. J. Microbiol. Biotechnol. 25:1305-1311.

Donio MBS, Ronica SFA, Viji VT, Velmurugan S, Jenifer JA, Michaelbabu M, Citarasu T, 2013. Isolation and characterization of halophilic Bacillus sp. BS3 able to produce pharmacologically important biosurfactants. Asian. Pac. J. Trop. Med. 6:876-883.

Dunlap CA, Kwon SW, Rooney AP, Kim SJ, 2015. Bacillus paralicheniformis sp. nov., isolated from fermented soybean paste. Int. J. Syst. Evol. Micr. 65:3487-3492.

Dunlap CA, Schisler DA, Perry EB, Connor N, Cohan FM, Rooney AP, 2017. Bacillus swezeyi sp. nov. and Bacillus haynesii sp. nov., isolated from desert soil. Int. J. Sys. Evol. Micr. 67:2720-2725.

Fan B, Blom J, Klenk HP, Borriss R, 2017. Bacillus amyloliquefaciens, Bacillus velezensis, and Bacillus 
siamensis form an "operational group B. amyloliquefaciens" within the B. subtilis species complex. Front. Microbiol. $8: 22$.

Farrar WE Jr, 1963. Serious infection due to "non-pathogenic" organisms of the genus Bacillus. Review of their status as pathogens. Am. J. Med. 34:134-141.

Feinberg L, Jorgensen J, Haselton A, Pitt A, Rudner R, Margulis L, 1999. Arthromitus (Bacillus cereus) symbionts in the cockroach Blaberus giganteus: dietary influences on bacterial development and population density. Symbiosis 27:109-123.

Fry JC, 2004. Culture-dependent microbiology, p. 80-87. In: A.T. Bull (ed.), Microbial diversity and bioprospecting. American Society of Microbiology, Washington, DC.

Ghosh A, Dey N, Bera A, Tiwari A, Sathyaniranjan KB, Chakrabarti K, Chattopadhyay D, 2010. Culture independent molecular analysis of bacterial communities in the mangrove sediment of Sundarban. India. Saline Systems 6:1-11.

Guixa-Boixareu N, Calderón-Paz J, Heldal M, Bratbak G, Pedrós-Alió C, 1996. Viral lysis and bacterivory as prokaryotic loss factors along a salinity gradient. Aquat. Microb. Ecol. 11:215-227.

Holguin G, Gonzalez-Zamorano P, De-Bashan LE, Mendoza R, Amador E, Bashan Y, 2006. Mangrove health in an arid environment encroached by urban development - a case study. Sci. Total. Environ. 363:260-274.

Javor BJ, 2012. Hypersaline environments: microbiology and biogeochemistry. Springer -Verlag: 328 pp.

Jasim B, Sreelakshmi S, Mathew J, Radhakrishnan EK, 2016. Identification of endophytic Bacillus mojavensis with highly specialized broad spectrum antibacterial activity. 3 Biotech. 6:187.

La Jeon Y, Yang JJ, Kim MJ, Lim G, Cho SY, Park TS, Suh JT, Park YH, Lee MS, Kim SC, Lee HJ, 2012. Combined Bacillus licheniformis and Bacillus subtilis infection in a patient with oesophageal perforation. J. Med. Microbiol. 61:1766-1769.

Janek T, Łukaszewicz M, Rezanka T, Krasowska A, 2010. Isolation and characterization of two new lipopeptide biosurfactants produced by Pseudomonas fluorescens BD5 isolated from water from the Arctic Archipelago of Svalbard. Bioresour. Technol. 101:6118-6123.

Jørgensen JN, Laguna JS, Millán C, Casabuena O, Gracia MI, 2016. Effects of a Bacillus-based probiotic and dietary energy content on the performance and nutrient digestibility of wean to finish pigs. Anim. Feed Sci. Technol. 221:54-61.

Kaewtapee C, Burbach K, Tomforde G, Hartinger T, CamarinhaSilva A, Heinritz S, Seifert J, Wiltafsky M, Mosenthin R, Rosenfelder-Kuon P, 2017. Effect of Bacillus subtilis and Bacillus licheniformis supplementation in diets with lowand high-protein content on ileal crude protein and amino acid digestibility and intestinal microbiota composition of growing pigs. J. Anim. Sci. Biotechnol. 8:37.

Kaur I, Das AP, Acharya M, Klenk HP, Sree A, Mayilraj S, 2012. Planococcus plakortidis sp. nov., isolated from the marine sponge Plakortis simplex (Schulze). Int. J. Syst. Evol. Micr. 62: 883-889.

Kiran GS, Thomas TA, Selvin J, Sabarathnam B, Lipton AP, 2010. Optimization and characterization of a new lipopeptide biosurfactant produced by marine Brevibacterium aureum MSA13 in solid state culture. Bioresour. Technol. 101: 2389-2396.
Kumar S, Stecher G, Tamura K, 2016. MEGA7: molecular evolutionary genetics analysis version 7.0 for bigger datasets. Mol. Biol. Evol. 33: 1870-1874.

Li L, Mendis N, Trigui H, Oliver JD, Faucher SP, 2014. The importance of the viable but non-culturable state in human bacterial pathogens. Front. Microbiol. 5:258.

Lane DJ, 1991. 16S/23S rRNA sequencing, p. 115-175. In: E. Stackebrandt and M. Goodfellow (eds.), Nucleic acid techniques in bacterial systematics. Wiley \& Sons, Chichester.

Larkin MA, Blackshields G, Brown NP, Chenna R, McGettigan PA, McWilliam H, Valentin F, Wallace IM, Wilm A, Lopez R, Thompson JD, 2007. Clustal W and Clustal X version 2.0. Bioinformatics 23:2947-2948.

Larsen N, Thorsen L, Kpikpi EN, Stuer-Lauridsen B, Cantor MD, Nielsen B, Brockmann E, Derkx PM, Jespersen L, 2014. Characterization of Bacillus spp. strains for use as probiotic additives in pig feed. Appl. Microbiol. Biotechnol. 98:1105-1118.

Lee SY, Dunn RJK, Young RA, Connolly RM, Dale PER, Dehayr R, Lemckert CJ, McKinnon S, Powell B, Teasdale PR, Welsh DT, 2006. Impact of urbanization on coastal wetland structure and function. Austral. Ecol. 31:149-163.

Liang JB, Chen YQ, Lan CY, Tam NF, Zan QJ, Huang LN, 2007. Recovery of novel bacterial diversity from mangrove sediment. Mar. Biol. 150:739-747.

Ma C, Zhou S, Lu Q, Yang G, Wang D, Zhuang L, Li F, Lei F, 2013. Decolorization of Orange I under alkaline and anaerobic conditions by a newly isolated humus-reducing bacterium, Planococcus sp. MC01. Int. Biodeter. Biodegr. 8:17-24.

Lima TM, Fonseca AF, Leão BA, Mounteer AH, Tótola MR, Borges AC, 2011. Oil recovery from fuel oil storage tank sludge using biosurfactants. J. Bioremed. Biodegrad. 2:104172.

Mandell GL, Bennett JE, Dolin R, 2010. Mandel, Douglas and Bennett's principles and practice of infectious diseases, 7 th ed. Churchill Livingstone, Philadelphia.

Martínez Cruz P, Ibáñez AL, Monroy Hermosillo OA, Ramírez Saad HC, 2012. Use of probiotics in aquaculture. ISRN Microbiology 2012;2012:916845.

Meidong R, Doolgindachbaporn S, Jamjan W, Sakai K, Tashiro Y, Okugawa Y, Tongpim S, 2017. A novel probiotic Bacillus siamensis $\mathrm{B} 44 \mathrm{v}$ isolated from Thai pickled vegetables (Phak-dong) for potential use as a feed supplement in aquaculture. J. Gen. Appl. Microbiol. 63:246-253.

Meng QW, Yan L, Ao X, Zhou TX, Wang JP, Lee JH, Kim IH, 2010. Influence of probiotics in different energy and nutrient density diets on growth performance, nutrient digestibility, meat quality, and blood characteristics in growing-finishing pigs. J. Anim. Sci. 8:3320-3326.

Mondal KC, Pati BR, 2000. Studies on the extracellular tannase from newly isolated Bacillus licheniformis KBR 6. J. Basic Microbiol. 4:223-232.

Nakagawa Y, Sakane T, Yokota A, 1996. Emendation of the genus Planococcus and transfer of Flavobacterium okeanokoites Zobell and Upham 1944 to the genus Planococcus as Planococcus okeanokoites comb. nov. Int. J. Syst. Evol. Microbiol. 46: 866-870.

Nicholson WL, 2002. Roles of Bacillus endospores in the environment. Cell. Mol. Life. Sci. 59:410-416. 
Pacwa-Plociniczak M, Plaza GA, Piotrowska-Seget Z, Cameotra SS, 2011. Environmental applications of biosurfactants: recent advances. Int. J. Mol. Sci. 12:633-654.

Palmisano MM, Nakamura LK, Duncan KE, Istock CA, Cohan FM, 2001. Bacillus sonorensis sp. nov., a close relative of Bacillus licheniformis, isolated from soil in the Sonoran Desert, Arizona. Int. J. Syst. Evol. Micr. 51:1671-1679.

Por FD, 1980. A classification of hypersaline waters, based on trophic criteria. Mar. Ecol. 1:121-131.

Ruiz-Garcia C, Bejar V, Martinez-Checa F, Llamas I, Quesada E, 2005. Bacillus velezensis sp. nov., a surfactant-producing bacterium isolated from the river Velez in Malaga, southern Spain. Int. J. Syst. Evol. Microbiol. 55: 191-195.

Salehipour Milani A, Jafar Beglu M, 2012. Satellite-based assessment of the area and changes in the mangrove ecosystem of the Qeshm Island, Iran. J. Environ. Res. Dev. 7:1052-1060.

Stenfors Arnesen LP, Fagerlund A, Granum PE, 2008. From soil to gut: Bacillus cereus and its food poisoning toxins. FEMS Microbiol. Rev. 32:579-606.

Stoica C, Sorescu I, 2017. ABIS online - Advanced Bacterial Identification Software, an original tool for phenotypic bacterial identification. Regnum Prokaryotae 10:1-13. Available from http://www.tgw1916.net/bacteria logare desktop.html

Thu PM, Populus J, 2007. Status and changes of mangrove forest in Mekong Delta: Case study in Tra Vinh, Vietnam. Estuar. Coast. Shelf Sci. 71:98-109.

Thwaite JE, Atkins HS, 2012. Bacillus: Anthrax; food poisoning, p. 237-244. In: D. Greenwood, M. Barer, R. Slack and W. Irving (eds.), Medical microbiology. Elsevier, Amsterdam.

Valentine DL, 2007. Adaptations to energy stress dictate the ecology and evolution of the Archaea. Nat. Rev. Microbiol. 5:316-323.

Vasavada SH, Thumar JT, Singh SP, 2006. Secretion of a potent antibiotic by salt-tolerant and alkaliphilic actinomycete
Streptomyces sannanensis strain RJT-1. Curr. Sci. 91:13931397.

Ventosa A, 2006. Unusual micro-organisms from unusual habitats: hypersaline environments, p. 223-254. In: N.A. Logan, H.M. Lappin-Scott and P.C.F. Oyston (eds.), Proceedings SGM Symposium 66: Prokaryotic diversity mechanisms and significance. Cambridge University Press, Cambridge;

Wei X, Ji Z, Chen S. 2010. Isolation of halotolerant Bacillus licheniformis WX-02 and regulatory effects of sodium chloride on yield and molecular sizes of poly- $\gamma$-glutamic acid. Appl. Biochem. Biotechnol. 160:1332-1340.

Yan L, Guizhu C, 2007. Physiological adaptability of three mangrove species to salt stress. Acta Ecol. Sinica 27:22082214.

Yeon SH, Jeong WJ, Park JS, 2005. The diversity of culturable organotrophic bacteria from local solar salterns. J. Microbiol. 43:1-10.

Yoon JH, Weiss N, Kang KH, Oh TK, Park YH, 2003. Planococcus maritimus sp. nov., isolated from sea water of a tidal flat in Korea. Int. J. Syst. Evol. Microbiol. 53:20132017.

Yoon YJ, Im KH, Koh YH, Kim SK, Kim JW, 2003. Genotyping of six pathogenic Vibrio species based on RFLP of $16 \mathrm{~S}$ rDNAs for rapid identification. J. Microbiol. 41 312-319.

Zahed MA, Rouhani F, Mohajeri S, Bateni F, Mohajeri L, 2010. An overview of Iranian mangrove ecosystems, northern part of the Persian Gulf and Oman Sea. Acta Ecol. Sinica 30:240-244.

Zeigler DR, Perkins JB, 2015. The genus Bacillus, p. 309-337. In: E. Goldman and L.H. Green 2nd (eds.), Practical handbook of microbiology. CRC Press, Boca Raton.

Zhang X, Gao J, Zhao F, Zhao Y, Zhanshuang L, 2014. Characterization of a salt-tolerant bacterium Bacillus sp. from a membrane bioreactor for saline wastewater treatment. J. Environ. Sci. 26:1369-1374. 